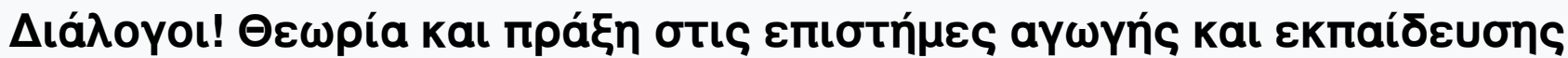

Tóp. 5 (2019)

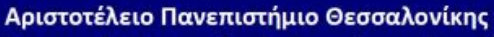

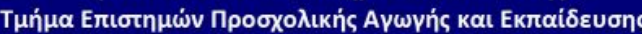

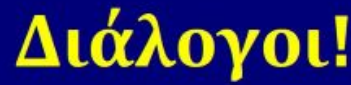

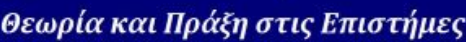

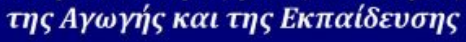

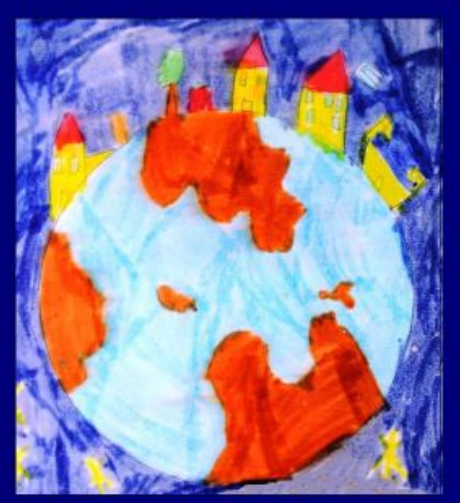

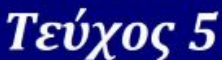 2019}

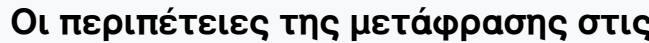

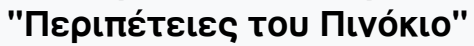

Mary Drosopulos, Sofia Gavriilidis

doi: $10.12681 /$ dial.16362

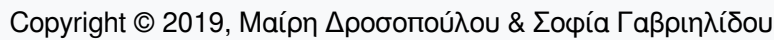

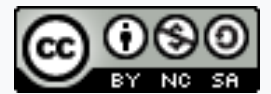

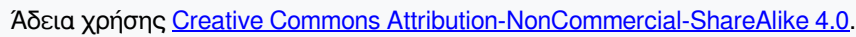

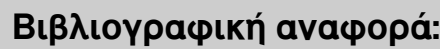

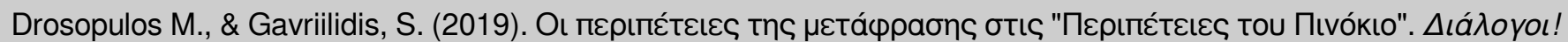

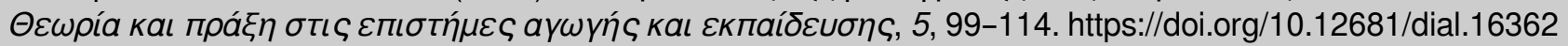




\title{
The adventures of translation in The Adventures of Pinocchio
}

\author{
Mary Drosopulos \\ Sofia Gavriilidis \\ Aristotle University of Thessaloniki \\ Aristotle University of Thessaloniki
}

\begin{abstract}
Research over the recent decades in the field of translation and cultural studies has shown that, during the transfer of a literary text from a linguistic/cultural system to another, modifying mechanisms are employed. According to relevant studies, the analysis of how translators manage culturally exotic elements provides insights into the dynamics of the intercultural function of the translated text; the text itself is also indicative of the ideological values promoted by the domestic book industry. Specifically, in the case of children's fiction, studies have shown strong modifying interventions in translation. This tendency has triggered doubts over the notions of interculturality and integration allegedly connected with Children's Literature.

The present paper explores diversity in translated children's literature by juxtaposing recent translations of the classic book The Adventures of Pinocchio in Greek and Turkish with the original Italian text. The descriptive translation studies have been used as a point of reference. Translators' strategies are examined and commented upon in relation with the values and principles of the target culture and the sociopolitical context of the period during which each translated version was published. The comparative study of the translated texts has shown that Greek translations tend to be more faithful to the original text, while the Turkish translations manifest an inclination to moral values connected with national and religious ideals.
\end{abstract}

Keywords: Translated children's literature, Descriptive Translation Studies, translation strategies, The Adventures of Pinocchio

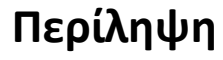

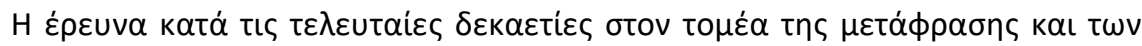

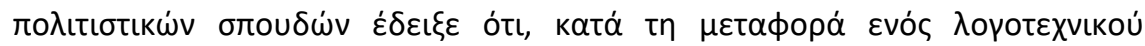

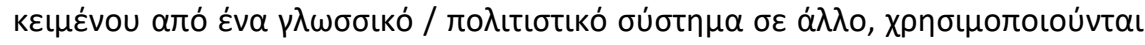

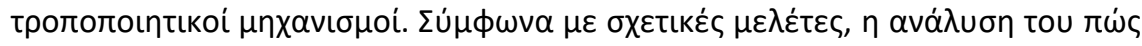

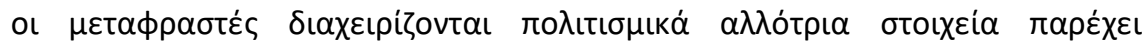

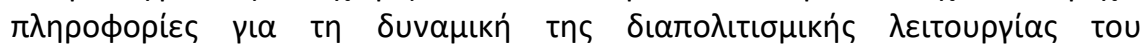

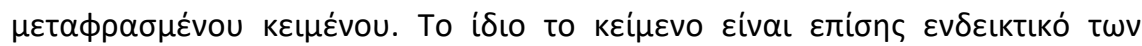

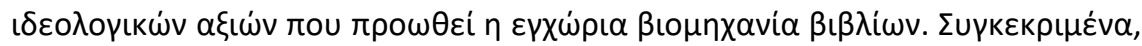

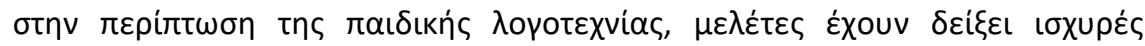

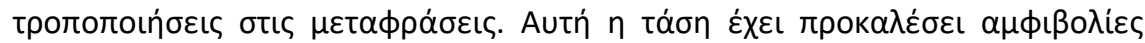

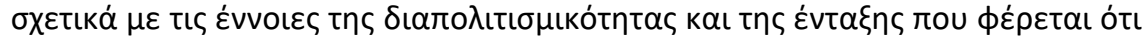

Correspondent author: Mary Drosopulos, m.drosopoulou@gmail.com, Interculturel and Translation Studies, PhD, Aristotle University of Thessaloniki 


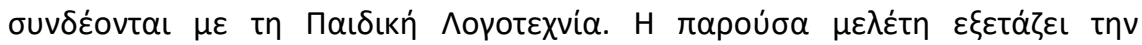

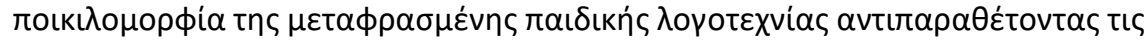

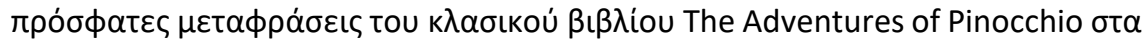

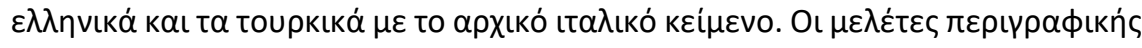

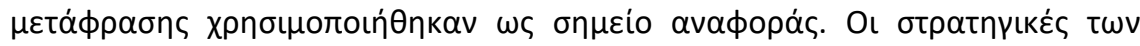

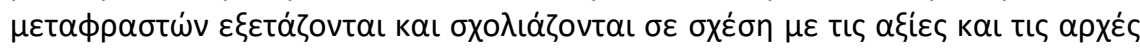

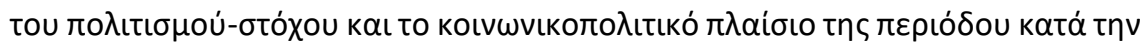

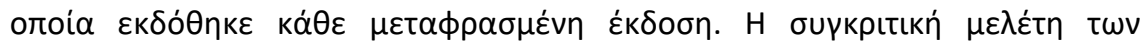

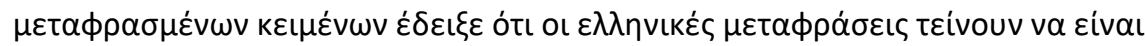

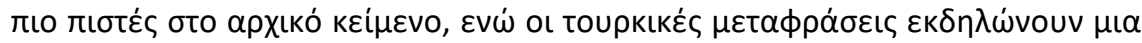

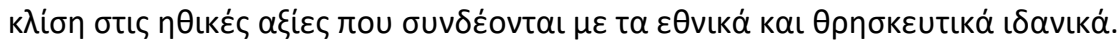

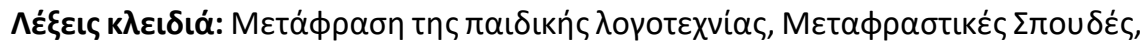

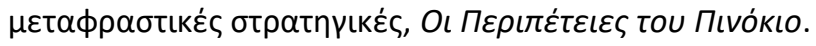

\section{Introductory comments}

The Adventures of Pinocchio is probably one of the most translated works, after the Bible and the Quran (Marcheschi, 1995, p. XI) and at the same time, one of the most adapted books for children. One hundred and thirty years after its first publication, the book continues to be revisited and re-interpreted. Addressing a dual audience, appealing to both adults and children as readers, the work is dominated by two conflicting ideologies: one abiding by the social ethics, the didactic style, institutions, ideology and main principles of the time during which it was created, and another one, criticizing and parodying these very same values (Gavriilidis, 2011). Furthermore, The Adventures of Pinocchio is a work challenging to translate due not only to its sophisticated narrative patterns, but also its abundance in instances of subtle irony and exaggeration. The book is written in a humorous style; its playful cynicism, however, co-exists with an intensely didactic tone, evident both in the narrative body and the heroes' dialogues.

For all the aforementioned reasons, the translations and adaptations of this classic book have been the subject of a wide variety of studies (indic. Cusatelli, 2002; Paruolo, 2005, 2001). However, the clear majority of these studies are based on synchronic and diachronic translations that belong exclusively to western cultural systems. Despite the relative cultural homogeneity of the western world, research has indicated that the translated text undergoes profound adaptations and alterations; this phenomenon provides a platform for constructive debate concerning various issues connected with children's literature. Despite the presence of various studies on the translation and adaptation strategies of The Adventures of Pinocchio, shedding light on the ideology attributed to the book by national children's literatures of the West, we know very little about the modifications it has undergone in non-western linguistic/cultural systems.

It is important to note that research on translated children's literature featuring non-western models is extremely limited (Lathey, 2006). Despite the fact that the international academic realm of $\mathrm{TCL}$ has been and continues to be enriched with prominent studies (indic: Lathey, 2006, 2010; Meek, 2001; Nikolajeva, 2006; Oittinen, 2000; O' Sullivan, 2005; Pinsent, 2006), the research focus remains mainly on the translated literature of European countries. Two prominent works are Children's Fiction in the hands of translators by Göte Klingberg (1986, cited in O' Sullivan, 2005) and the Poetics of Children's Literature by Zohar Shavit (1986). Göte Klingberg highlights and 
analyses the most common interventions in the translation of books for children, suggesting that the "foreign spirit" should be maintained where possible, so that young readers can experience the exotic culture of the book. Zohar Shavit, using the polysystem theory as a point of reference, concludes that the translation of children's literature is molded by the general cultural context existing at the time of production. These two key findings will become evident in the hereby paper, too.

Contemporary research on TCL has focused primarily on the produced text in relation to the cultural reality surrounding it. It has become clear that in translated children's texts, all kinds of modifications, adjustments, eliminations and additions arise from the following factors: firstly, the idiosyncrasy, pedagogic objectives and status quo prevailing in the target-culture, secondly, the ideology promoted by the original text and thirdly, the translator's personal values and beliefs. Practically speaking, all these aspects of the produced text are shaped by cultural standards connected with ethnicity, social structures, folk traditions, customs and habits, childhood, educational objectives and, finally, expectations concerning the younger generation of the target-culture.

The domestic publishing industry also intervenes in the translation process in adjusting a text to the values of the target-culture and in rendering it comprehensible, acceptable and appropriate for children. Before reaching young readers, a book passes through many stages (Alvstad, 2003; Goldthwaite, 1996), all of which are always controlled by adults. Translation, therefore, is also subject to the principles imposed by various forms of power.

During the translation of any literary text, regardless of whether it addresses children or adults, there are points calling for the translator's attention. When it comes to the translation of children's literature in particular, the translator's challenges are more in number and far more complicated than those of the translator who addresses adults. Dilemmas naturally go beyond the genre-based traits of the act of translating in itself. A core dilemma stems from the contradiction between the distinct purposes served by translated children's literature on the one hand and children's literature on the other: while the former aspires to affiliate the child-reader with unfamiliar cultural realms, the latter aims at socializing the reader into the existing, surrounding reality.

Taking all these points into account, one could, erroneously, conclude that cultural adaptations distort the meaning of the original text, thus affecting its aesthetics and eliminating its intercultural function. Obviously, when there is no cultural equivalence, adaptation is required. Translation, however, should primarily respect the source-text and oscillate eloquently between the two cultural realities that it expresses. A literary work addressing children is judged not only by its textual traits, but also by its extratextual elements, as well as its dynamics in reaching young readers and in contributing to their socialization (O'Sullivan, 2005).

Within this framework, the hereby paper examines the original text of The Adventures of Pinocchio in parallel with its translations into Greek and Turkish, with the aim of observing and analyzing cultural context adaptations.

Despite Turkey's geographical proximity to Greece and shared traditions between the two countries, there are vast differences between the two when it comes to dominant cultural practices such as religious expression and faith. The parallel study of the way the two countries treat and promote their children's literature in translation, can serve as a 
platform for debate on the intercultural dynamics of translated children's literature in a globalized world.

\section{The research: Research material, selection criteria and methodological approaches} Pinocchio:

The research was based on the following translations of The Adventures of

Collodi, C. (1999). Pinokyo. (H. Parisi, Trans.). Istanbul: Epsilon.

Collodi, C. (2005). Pinokyo. (G .Süveren, Trans.). Istanbul: AltinKitaplar.

Collodi, C. (2005). Pinokyo. (Z. Tokgöz, Trans.). Istanbul: Kervan.

Collodi, C. (2006). Pinokyo. (E. Berköz, Trans.). Istanbul: Türkiye İş Bankası Kültür Yayınları.

Collodi, C.(2011). Pinokyo. (E. Berköz, Trans.) Istanbul: Türkiye Iş̧ Bankası Kültür Yayınları.

Kollodi, K. (1991). The Adventures of Pinocchio. (M. Grammatikou, Trans.). Athens: Patakis.

Kollodi, K. (199x). Pinocchio. (S. Salimba, Trans.). Athens: Gemantzopoulos.

Kollodi, K. (2003). The Adventures of Pinocchio (A. Logotheti, Trans.). Athens: Ioannou.

Kolodi, K. (2004). The Adventures of Pinocchio (S. Kakisis, Trans). Athens: Erato.

Kolodi, K. (2006). Pinocchio (A. Vrana, Trans.). Athens: Agkyra.

The first criterion for the selection of the hereby editions has been the publication date; we opted for recent translations of The Adventures of Pinocchio, ranging from the early nineties till today. The second criterion was popularity and accessibility; the versions examined are easily accessible to children in bookstores or libraries in Greece and Turkey. Furthermore, the final books selected are unique when compared with each other; they exhibit very distinct approaches not only in content but also in style. There have been interesting findings even in introductory notes, peritextual elements, illustration or the way the chapters have been organized. It would be impossible to include all these examples in a paper; there will be, therefore, selected references, indicative of certain ideological tendencies.

Concerning the English version of the book, the selection was based on a simple yet solid criterion; the edition supported by the Fondazione Nazionale "Carlo Collodi", Pescia (2000), translated in 1983 by M. L. Rosenthal.

In regard to theoretical analysis, the respective translation strategies observed are viewed within the theoretical framework developed by James S. Holmes (1972) in the 1970s, on which the theory of descriptive studies by Gideon Toury (1995) was based. According to Holms, the descriptive translation studies aim to "describe the particular phenomena in the world of our experience and to establish general principles by means of which they can be explained and predicted. As a field of pure research [...] translation studies thus have two main objectives: (1) to describe the phenomena of translating and translation(s) as they manifest themselves in the world of experience and (2) to establish general principles by means of which these phenomena can be explained and predicted. The two branches of pure translation studies concerning themselves with these objectives 
can be designated descriptive translation studies or translation description and theoretical translation studies or translation theory." (Holmes, [1972] 2000, p. 176). Descriptive translation studies are distinguished by their focus as product-oriented, function-oriented, and process-oriented. In our study, we will reflect on the new traits of the translated product in relation to the cultural context of the audience it addresses (function-oriented).

'Domestication' and 'foreignization' are two terms used by Lawrence Venuti (1995: 19-20 1 1986) to define the two basic strategies adopted during the process of translation. Domestication is an ethnocentric reduction of the foreign text to targetlanguage cultural values, bringing the author 'back home'. Foreignization is an ethnodeviant pressure on those values to register the linguistic and cultural difference of the foreign text, 'sending the reader abroad'. In practice, most texts combine both strategies; this fact is even more common and evident in books for children, which are expected to abide by the standards of the target culture.

\section{"Interpreting the translations"}

It is important to note that every translator applies alternately, in the same text, more or less, both the domestication and the foreignization strategy. At certain cases, modifications are quite strong, implying an adaptation instead of a translation. The hereby paper, however, uses the term "translation" instead of "adaptation", considering that all translations involve adaptation to a certain degree (Oittinen, 2000, p. xiv).

A key finding is that the element of religion and, in the specific case, Islam, becomes a central trait in some translations into Turkish. A typical example is from the controversial Turkish version of the Kültür editions (2011), where Geppetto (nickname for the Italian name Giuseppe which alludes to Joseph) is renamed Galip Usta; a name directly connected with the Muslim tradition. The name Galip (originally Ghalib in Arabic) means "victorious" or "conqueror"; it is name which is strongly connected with the ottoman tradition and the Islamic ethos. 'Usta', on the other hand, means 'master/adept' and it is a title given in Turkish to experienced craftsmen. Gepetto is a carpenter, after all. Another obvious reference to Turkish identity is made through the hero's depiction: Galip (in other words, Gepetto), is illustrated wearing a fez instead of the beret that the hero of the original text is wearing. A "fez" is a felt cap, usually of a red color, having the shape of a truncated cone and is considered the national headdress of the Turks.

In other instances, one witnesses direct references not only to national values and symbols, but also to Islamic ideals and practices. The religious dimension of The Adventures of Pinocchio, and particularly, the allusions to Islam in its Turkish translations become evident not only in the cases when translators add to the text religious symbolism connected with the target-culture, but also each time they deliberately omit religious references of the source text. For instance, in the Turkish translation of the Epsilon editions (1999) certain allusions to the Christian faith have been omitted; there is no reference to the "seven deadly sins" (sette come i peccati mortali), which is a pillar of Christianity. The Turkish translator of the Kültür version (2011) has chosen a different path, substituting the specific phrase by another one meaning "seven goats ate the rat!". By this technique, religious connotations have been avoided, but the meaning of the original text has also changed completely. 
The Greek translations, on the other hand, focus mainly on the number seven and provide different versions connected with religion: As we see in the following table, the seven 'sins' have been translated as seven 'wounds', although the latter produce different connotations in the context of the Greek Orthodox faith compared to the Roman Catholic faith. Another Greek translator preserves only the number seven and converts the seven deadly sins into the "seven wonders of antiquity". This is a translation which is inconsistent with the original idea because it carries a positive meaning, in contrast with the notion of the deadly sins, which has only negative connotations (see Table 1).

\begin{tabular}{|c|c|c|}
\hline Paggi, 1883, cap. Xxvii & FNCC, 2000 & loannou, 2004 \\
\hline $\begin{array}{l}\text {...sei solo e noi siamo sette. } \\
\text { - Sette come i peccati mortali } \\
\text {-disse Pinocchio con una } \\
\text { grande risata. } \\
\text {-Avete sentito, ci ha insulato } \\
\text { tutti. Ci ha chiamato col nome } \\
\text { di peccati mortali! } \\
\text {-Pinocchio! chiedici scusa } \\
\text { dell'offesa ...o se no, guai a te! } \\
\text {-Cucù! Fece il burattino ... }\end{array}$ & $\begin{array}{l}\text {...there's only one of you and } \\
\text { there are seven of us. } \\
\text {-Sure, seven - like the seven } \\
\text { deadly sins, said Pinocchio, } \\
\text { with a defiant laugh. } \\
\text {-Did you hear what he said? } \\
\text { He's insulting us all! He called } \\
\text { us the seven deadly sins. } \\
\text {-Better apologize Pinocchio! If } \\
\text { you don't, you are in trouble! } \\
\text {-You're cuckoo! jeered the } \\
\text { puppet... }\end{array}$ & 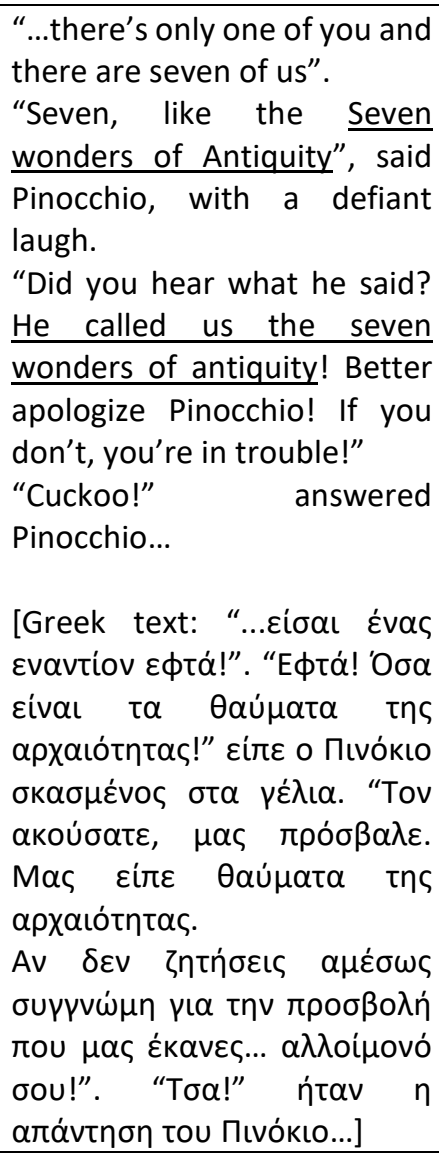 \\
\hline Gementzopoulos, 1995 & Epsilon, 1999 & Kultur, 2011 \\
\hline $\begin{array}{l}\text {... there's only one of you and } \\
\text { there are seven of us. } \\
\text {-Seven, like the Seven } \\
\text { Wounds!, said Pinocchio } \\
\text { laughing. } \\
\text {-Did you hear what he said? } \\
\text { He called us the seven } \\
\text { wounds! Pinocchio, you'd } \\
\text { better take that back or you'll } \\
\text { be sorry! } \\
\text {-Cuckoo! Said the puppet... }\end{array}$ & $\begin{array}{l}\text {...there's only one of you and } \\
\text { there are seven of us. } \\
\frac{\ldots . . .}{\text { Cuckoo! }} \\
\text { [Turkish text: -Sen teksin, } \\
\text { bizse yedi kişiyiz.-Nanik!] }\end{array}$ & $\begin{array}{l}\text {...there's only one of you and } \\
\text { there are seven of us. } \\
\text {-Seven goats ate the rat! } \\
\text {-Did you hear what he said? } \\
\text { He's insulting us all! He told us } \\
\text { to eat the rat! } \\
\text { [Turkish text: sen bir kişisin, } \\
\text { bizse yedi. -Yedi keçi sıçanı } \\
\text { yedi!] }\end{array}$ \\
\hline
\end{tabular}




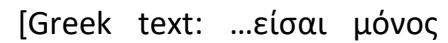

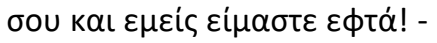

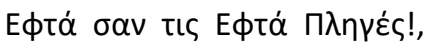

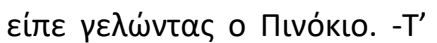

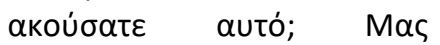

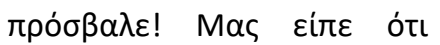

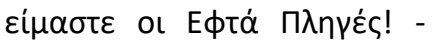
Пıvókıо, $\pi \varepsilon \varsigma ~ \mu \alpha \varsigma$ ótı тo

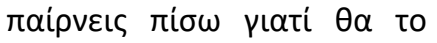

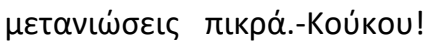

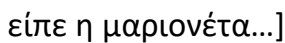

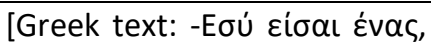
$\varepsilon v \omega \dot{~ \varepsilon \mu \varepsilon i \varsigma ~ \varepsilon \phi \tau \alpha ́ ~ \alpha ́ t o \mu \alpha . ~ N \alpha ~ v \alpha ~}$ $v \alpha \vee \alpha \ldots]$

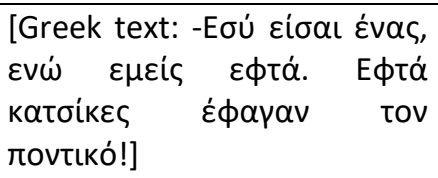

Table 1

Reformulations of the phrase "seven deadly sins" during the translation process (the underlined phrases highlight the differentiations made, facilitating, thus, the understanding of the respective comments)

At this point, we should stress that, although the book The Adventures of Pinocchio promotes universal values and morals, the story does not make direct references to religious practices and beliefs, despite the fact that the author, Carlo Collodi was a profoundly religious man, who had even attended in his youth the religious school Scuola degli Scopoli. In his book, there are indeed allusions to credos of the Christian Church, such as the Gift of Life to Man from his Creator, original sin or Man's pathos towards temptation. Furthermore, certain aspects of the story allude to scenes taken from the Bible; for example, the scene where Geppetto is trapped in the stomach of the beast reminds us of the parable of Jonas. Similarly, the image of Pinocchio hanging from the branch of a large oak tree alludes to the Crucifixion of Jesus. Nevertheless, we should clarify that these myths and symbolisms imply a universal code of morals and not a strictly Christian one, since there are no traces in the book of any kind of religious typology, be it Christian, or any other religious convention. In certain Turkish translations, however, the element of religion, and particularly Islam, manifests itself in scenes where the original text not only discourages religious connotations, but also expresses irony towards the hero's situation. For instance, when Pinocchio, on his way to the "Land of Toys", suddenly observes that: "This donkey weeps", Little Man, another wrenched figure that Pinocchio meets on the street, answers by saying: "Let him cry! He'll laugh again on the day he gets married!" (Lascialo piangere: riderà quando sarà sposo, cap. xxxi). This is an idiom meaning that one should not worry or nag over small things. In all versions examined, this phrase has been literally translated into Greek [Let him cry! He'll laugh again on the day he gets married], causing confusion to the Greek reader, who cannot see the point of the metaphor or proverbial saying. In contrast, in the Turkish version of 2005 by Kitaplar Editions, we see a case of adaptation to the cultural context of the country: "Let him cry, he will laugh at the Bayram of the Donkeys". Bayram is the Turkic word for a nationally celebrated festival or holiday.

Collodi's subtle irony is another challenge that the translator needs to face. When asked by the giant owner of the Puppet Theatre "what does he [your father] do for a living?" Pinocchio replies: "He is poor". Humor is conveyed by Pinocchio's naïve and unexpected answer. Being "poor" is not a profession, it is a state, but the state of poverty 
is a result of Geppetto's profession. If the translator considers that the child-reader is not mature enough to understand humor, then s/he will provide clarification, such as "He is doing a job that fits a very poor man or He is just poor" (ed. Epsilon, 1999; ed. Kitaplar, 2005; ed. Kültür, 2011). We observe that the syntax of the phrase has been changed and the humorous effect has been lost. The Greek version "He is a beggar" (ed. Agkyra, 2006) eliminates the humor in this case and also communicates a false impression, which completely distorts Geppetto's character. In other parts of the book, we see that the Greek translation (ed. loannou) makes good use of the linguistic assets of the targetculture in a relatively liberal and creative way; the translator tends to be inventive and succeeds even in communicating verbal humor without deviating from the original meaning of the text.

As we have already mentioned, the basic aim of children's literature is to socialize the child reader into the cultural standards of the reality surrounding him/her. In contrast, children's literature translation aims at familiarizing the young reader with different cultural realities. Consequently, when faced with this inner dilemma, the translator needs to decide on whether to follow either a creative or a didactic approach (see Table 2). The domestication strategy employed in the Turkish version of the Epsilon editions (1999) is presumably an attempt to socialize young readers into a particular culture by commenting on the social phenomenon of begging. Begging is not accepted as a practice in the realm of Islam, according to which everyone has to earn their living. It is due to this belief that there are few beggars in the streets of Turkey compared to other countries. Instead, one can see people in need, trying to sell their products to passersby, providing small services or even putting up little shows in the streets in order to gain money. This moral rule applies to all, irrespective of age or physical condition.

\begin{tabular}{|c|c|c|}
\hline Paggi, 1883, cap. Xxiv & FNCC, 2000 & Epsilon, 1999 \\
\hline $\begin{array}{l}\text { A chiedere elemosina si } \\
\text { vergognava: perché il suo } \\
\text { babbo gli aveva predicato } \\
\text { sempre che l'elemosina } \\
\text { hanno il diritto } \\
\text { di chiederla solamente i } \\
\text { vecchi e gl'infermi. } \\
\text { I veri poveri, in questo } \\
\text { mondo, meritevoli di } \\
\text { assistenza e di compas-sione, } \\
\text { non sono altro che quelli che, } \\
\text { per ragione d'età o di } \\
\text { malattia, } \\
\text { si trovano condannati a non } \\
\text { potersi più guadagnare il pane } \\
\text { col lavoro delle proprie mani. } \\
\text { Tutti gli altri hanno l'obbligo } \\
\text { di lavorare: se non lavorano e } \\
\text { patiscono la fame, tanto } \\
\text { peggio per loro. }\end{array}$ & $\begin{array}{l}\text { He was ashamed to beg. His } \\
\text { father had always taught him } \\
\text { that begging was wrong, } \\
\text { except if you're old or sick. } \\
\text { When you are really poor you } \\
\text { deserve help and sympathy, } \\
\text { and those who are too old and } \\
\text { sick to earn their bread } \\
\text { through the work of their } \\
\text { hands do, certainly, have a } \\
\text { right } \\
\text { to ask for what they need. But } \\
\text { the rest of us have a duty to } \\
\text { work. If we refuse and } \\
\text { therefore suffer from hunger, } \\
\text { so much } \\
\text { the worse for us. }\end{array}$ & $\begin{array}{l}\text { He was ashamed to beg. It } \\
\text { was everyone's duty to work. } \\
\text { [Turkish text: Dilenmeye } \\
\text { utanıyordu. Çalışmak } \\
\text { herkesin göreviydi.] }\end{array}$ \\
\hline Altin kitaplar, 2006 & Kültür, 2011 & \\
\hline
\end{tabular}




\begin{tabular}{|c|c|}
\hline $\begin{array}{l}\text { Pinocchio was too ashamed } \\
\text { to beg. His father had } \\
\text { repeatedly told him that if } \\
\text { people are not willing to work } \\
\text { and are therefore hungry, } \\
\text { then they are the ones to } \\
\text { blame. No one feels mercy for } \\
\text { this kind of people, he had } \\
\text { said. } \\
\text { [Turkish text: Pinokyo } \\
\text { dinlenmekten utanıyordu. } \\
\text { Babası ona birkaç kez, kişiler } \\
\text { çalışmaya yanaşmayıp aç } \\
\text { kalırlarsa suç yine } \\
\text { kendilerindedir. Böylelerine } \\
\text { de hiç kimse acımaz, demişti.] }\end{array}$ & $\begin{array}{l}\text { He was ashamed to seek } \\
\text { handouts. That was because } \\
\text { his father had always told him } \\
\text { that only the sick and the old } \\
\text { are entitled to accept charity. } \\
\text { The only ones in this world } \\
\text { who reserved this right were } \\
\text { those who were really poor } \\
\text { and genuinely deserved help } \\
\text { and mercy; the ones who } \\
\text { could not earn a living on their } \\
\text { own either because of illness } \\
\text { or because of age. Except for } \\
\text { these, everyone else was } \\
\text { obliged to work. If someone } \\
\text { opted to not work and stay } \\
\text { hungry instead, this was their } \\
\text { own conscious choice. } \\
\text { [Turkish text: Sadaka } \\
\text { istemeye utanıyordu. Babası } \\
\text { her zaman, yalnız hasta ve } \\
\text { yaşlı olanların sadaka } \\
\text { istemeye hakkı olduğunu } \\
\text { söylerdi çünkü. Bu dünyada } \\
\text { gerçek yoksullar, yardıma ve } \\
\text { acınmayahl hakkı olanlar, } \\
\text { yaşlılık yada hastalık } \\
\text { nedeniyle, ekmeklerini Kendi } \\
\text { el emekleriyle } \\
\text { kazanamayacak durumda } \\
\text { bulunanlardı yalnı. Bunların } \\
\text { dışında herkes çalışmak } \\
\text { zorundaydı. Çalışmayıp aç } \\
\text { kalırlarsa kendilerinin bileceği } \\
\text { işti bu.] }\end{array}$ \\
\hline
\end{tabular}

Table 2

Alteration of the theme of begging in translation

Another instance, which is suggestive of the religious influence can be traced in the humorous dialogue between Pinocchio and the terrifying puppet master Fire-Eater. At some part of the story, the Fire-Eater suddenly sneezes and this is in fact a narrative technique foreseing a positive twist in the story, as in older societies a sneeze was considered to be a sign a positive development (Marcheschi, 1995). In the Greek translation (ed. Patakis, 1992), when the Fire-Eater asks Pinocchio whether his parents are alive, the latter answers by mentioning the mother first, something which does not happen in the original text. This phenomenon is also observed in a Turkish translation (ed. Kervan, 2005), leading us to conclude that the mother figure was possibly more important in the translators' minds. Another interesting remark is that in a Greek edition (ed. Agkyra, 2006), instead of the typical expression "bless you" that is said to a person sneezing, the 
text says: "God bless you!" In other words, the element of a higher divine force is attributed to a stereotypical phrase, however, by employing the particular strategy, the translator simply tries to recreate the humorously pompous and excessively elevated dialogue between the two heroes. This is a technique which alludes to Collodi's theatrical background and which is employed by the author in various instances of the text as a vehicle by which he satirizes high-ranked people and institutions.

The Greek translations cited would also be interesting to analyze for instances such as the substitution of "daddy" (babbo) by "father" (see Table 3).

\begin{tabular}{|c|c|c|c|c|}
\hline $\begin{array}{l}\text { Paggi, 1883, } \\
\text { cap. xi }\end{array}$ & FNCC, 2000 & Patakis, 1992 & Agkyra, 2006 & Kervan, 2005 \\
\hline $\begin{array}{l}\text {... Etcì! etsì! - e } \\
\text { fece altri due } \\
\text { staturni. } \\
\text {-Felicità! -disse } \\
\text { Pinocchio. } \\
\text {-Grazie. E il tuo } \\
\text { babbo e la tua } \\
\underline{\text { mamma sono }} \\
\underline{\text { sempre vivi? }}\end{array}$ & $\begin{array}{l}\text {... Ah-choo! Ah- } \\
\text { Choo! And then } \\
\text { he sneezed } \\
\text { twice more. } \\
\text {-Bless you!, } \\
\text { said Pinocchio. } \\
\text {-Thank you! Are } \\
\text { your papa and } \\
\text { mama still alive? }\end{array}$ & 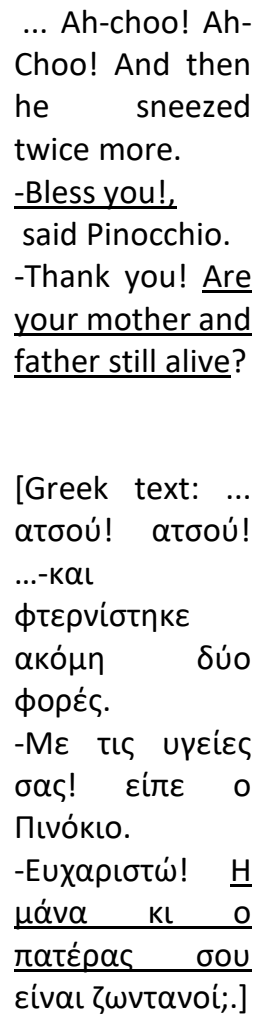 & 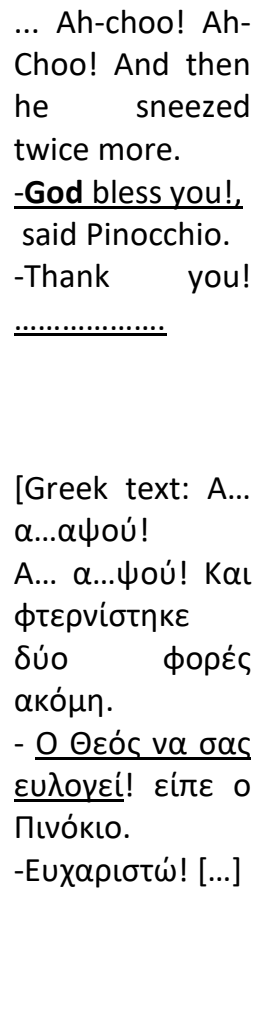 & $\begin{array}{l}\text {... Ah-choo! Ah- } \\
\text { Choo! And then } \\
\text { he sneezed } \\
\text { twice more. } \\
\text {-God bless you!, } \\
\text { said Pinocchio. } \\
\text {-Thank you! } \\
\text { How is your } \\
\text { mother and } \\
\text { father? May God } \\
\text { keep them in } \\
\text { good health. } \\
\text { [Turkish text: } \\
\text { Hapşu hapşu! Iki } \\
\text { kere üst üste } \\
\text { hapşırdı. } \\
\text {-Allah sizden razı } \\
\text { olsun efendim. } \\
\text {-Eksik olma! } \\
\text { Nasıl } \\
\text { anan, baban hâlâ } \\
\text { sağdırlar } \\
\text { ya inşallah.] }\end{array}$ \\
\hline
\end{tabular}

\section{Table 3}

Cultural adaptations to the values and ideals of the target-texts

In the hereby fragment, we will observe that the addition of the phrase Aman Yarabbi (Oh, Rabbi) aims only at reminding the readers of the religious/ethnic identity of the hero. Furthermore, the repetition of the phrase Ah, babacığım, babacığım! (Oh daddy, daddy!) (another addition by the translator) accentuates the importance of showing utter love and obedience to one's parents. We observe a similar tendency in the Greek translation, where the addition "I wouldn't be risking", expresses Pinocchio's remorse and self-criticism (see Table 4). The devotion to one's family is a common motif and a shared social value in both Greece and Turkey. 


\begin{tabular}{|c|c|c|c|}
\hline Paggi, 1883,cap.v & FNCC, 2000 & Erato, 2004 & Kervan, 2005 \\
\hline $\begin{array}{l}\text { Se non fossi scappato } \\
\text { di casa e se il mio } \\
\text { babbo fosse qui, ora } \\
\text { non mi troverei a } \\
\text { morire di sbadigle. } \\
\text { Oh! Che brutta } \\
\text { malattia che è la } \\
\text { fame! }\end{array}$ & $\begin{array}{l}\text { I was a bad boy to } \\
\text { fight with my papa } \\
\text { and run away from } \\
\text { home. If my papa } \\
\text { were only here now, I } \\
\text { wouldn't be dying of } \\
\text { yawns and hiccups! } \\
\text { Oh, it's miserable to } \\
\text { be hungry! }\end{array}$ & 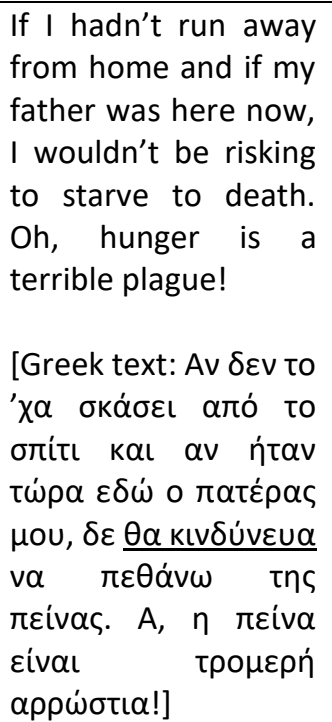 & $\begin{array}{l}\text { Oh, daddy, daddy! If } \\
\text { only he has here now, } \\
\text { would I be starving to } \\
\text { death? Oh my Rabbi, } \\
\text { what a terrible } \\
\text { disease! } \\
\text { [Turkish text: -Ah, } \\
\text { babacığım, } \\
\text { babacığım! Şimdi } \\
\text { Burada olsaydı, ben } \\
\text { açlıktan ölür müydüm } \\
\text { hiç? Aman Yarabbi ne } \\
\text { berbat bir } \\
\text { hastalıkmış!] }\end{array}$ \\
\hline
\end{tabular}

\section{Table 4}

Additions in translation aiming at reinforcing the dominant values of the targetcultures

The Adventures of Pinocchio is a book rich in anthroponyms, toponyms, as well as references to food, objects and symbolic practices. All these are in fact challenges for the translator. The sweet delicacies, like "pies and cakes and almond cookies and cream puffs" (una cantina di rosoli e di alchermes, e una libreria tutta piena di canditi, di torte, di panettoni, di mandorlati e di cialdonicolla panna, cap. xix), that Pinocchio is dreaming of have been adapted to the tastes of the Turkish cuisine, and become lokum, kurabiyeandkaymaklibiskuviler, while the aromatic and rich in alcohol elixirs of the time, like "rosoli and alchermes", have been omitted, probably because alcohol is forbidden to the practitioners of Islam. The "soundof pipes" (musica di pifferi e di colpi di gran cassa cap.ix) that enchants Pinocchio is turned into a sound of "davul and zurna" (drums and guitar) (Kültür,2011), buru (trumpettriton) (ed. Altın kitaplar, 2005) düdük (pipe) (Epsilon,1999) in the Turkish translation, as well as flute and drum (

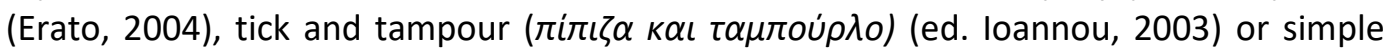

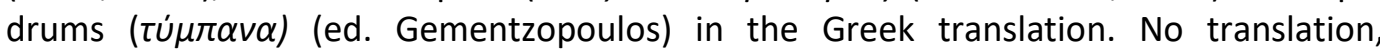
however, neither in Turkish nor in Greek has managed to transfer successfully the allegorical meaning of the following phrase: The sounds were coming from the end of a very long road that led away from the street he was on, where thes chool was, to a little village near the sea (quei suoni venivano di fondo a una lunghissima strada traversa che conduceva a un piccolo paesetto fabbricato sulla spiagia del mare), where narration foresees Pinocchio's slip. The crossroads in which the hero had found himself is in fact the point of his deviation, in other words, the point at which he stopped following the right path. The crossroads is an allegory for illegality or any deviation from rules. The straight road, on the contrary, driving to school, symbolizes the "right or the normal path" that a child of his age was supposed to have followed. 
When Lamp-Wick tries to convince Pinocchio to follow him to the Land of Toys (in chapter 30), one of his arguments are that over there are No schools, no teachers, no book - nobody ever has to do homework in that heavenly land. Thursday there's no school, and every week is made up of six Thursdays and one Sunday (Lì non vi sono scuole. Lì non vi sono maestri. Lì non vi sono libri. In quel paese benedetto non si studia mai. Il giovedì non si fa scuola: e ogni settimana è composta di sei giovedi e di una domenica, cap. $\mathrm{xx \textrm {x }}$ ). In the years during which Collodi lived, Thursday used to be a holiday, especially for the servants. Therefore, schools would be closed on Sundays and Thursdays, as well (Moschitta, 1990). In our days, Lamp-Wick's argument has no value, given that Thursday is not a school holiday. This is why in a few cases, both in Turkish and in Greek, the translators have slightly adjusted the dates so that the reading of the text can be functional.

Another very intriguing topic, which could actually form the basis of another study, would be the examination of the way that the titles of the 36 chapters of the book have been translated. Each title features a brief summary of the key points of the story; the way, however, by which upcoming events are presented tends to predispose the readers towards the plot, giving them hints about the hero's fate. Consequently, the way that these small texts have been translated is indicative of the translators' ideology, manifesting, thus, their interpretation of the moral repercussions of each chapter and eventually, their individual understanding of the message of the book, as a whole. In some translated versions, however, these texts have been omitted, simplified or substituted by chapter numbers.

There is a fairly large number of instances worth commenting in both translations; even the introductory comments or illustration and the peritextual elements are interesting for analysis. For reasons of space, it is impossible to include every interesting detail in this study. There is an anecdotal information however, which is worth sharing, for being a moment of glory for Collodi: the writer indirectly contributed to the educational reform of his country; in his works (which include original books but also texts in the "Macchiette" and "Occhi e nasi" collections), he used parody and satire to criticize the educational system and its institutions (Gavriilidis, 2004). He was also the author of school workbooks, such as "Sillabari, le Grammatiche, i Giannettini", the exact ones featured in the Adventures of Pinocchio, at the chapter where Pinocchio's classmates "began flinging books at him":

...spelling books, grammar books, dictionaries, books of stories, and all their other books. But Pinocchio our clever puppet had quick, sharp eyes. He dodged them all skilfully, and the books went flying over his head and into the sea. Well, imagine how all the fish in the water felt! They naturally supposed the books were some kind of food, and they swam up in great shoals to the top of the water. But once they nibbled on a page or two, or a frontispiece, they quickly spat it out with a disgusted expression, as if to say: "Ugh! This isn't our kind of food! We're used to something a lot better!"

[... cominciarono a scagliare contro di lui i Sillabari, le Grammatiche, $i$ Giannettini, i Minuzzoli, i Racconti del Thouar, il Pulcino della Baccini e altri libri scolastici: ma il burattino, che era d'occhio svelto e ammalizzito, faceva sempre civetta a tempo, sicché i volumi, passandogli di sopra al capo, andavano tutti a 
cascare nel mare. Figuratevi i pesci! I pesci, credendo che quei libri fossero roba da mangiare, correvano a frotte a fior d'acqua; ma dopo avere abboccata qualche pagina o qualche frontespizio, la risputavano subito, facendo con la bocca una certa smorfia, che pareva volesse dire: «Non è roba per noi: noi siamo avvezzi a cibarci molto meglio!] (cap. xxiv).

By referring to the titles of his own works, claiming that they are good for nothing and unworthy to be used even as fish food, Collodi reached the ultimate stage of satire, which is no other than self-parody. The "despicable" books that Collodi is referring to are in fact familiar to most Italian readers, but not to Greeks or Turks. Therefore, the faithful

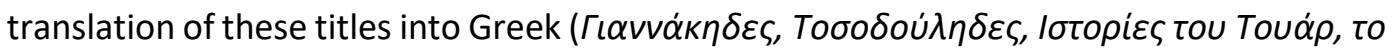

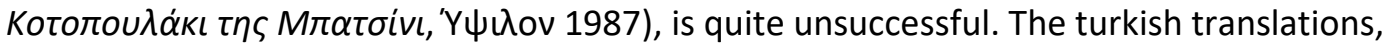
on the other hand, are either descriptive or opt for a culturally equivalent title.

The Kültür Editions (2011) have chosen a title in Turkish describing the thematic content or genre of the book: Aritmetik'leri, Okuma'ları (Arithmetics, Reading comprehension). In the cases of fiction, the original titles have been substituted by the titles of children's books which are famous in Turkey, such as Tom Amca'nın kulübesini (Uncle Tom's Cabin) and Pal Sokağının Çocukları (The Paul Street Boys), although The Paul Street Boys by Ferenc Molnár (1906) is a later work, published almost two decades after The Adventures of Pinocchio (1881-1882).

\section{Conclusion}

The Adventures of Pinocchio is a book which was written a long time ago and which is closely connected with the cultural reality of Tuscany. In its translations, cultural items that could have been considered a challenge have been substituted by cultural equivalents that have not altered seriously the original meaning. Translators have opted either for a domesticating or foreignizing approach, driven by their own perceptions with regards to the nature of the text and the needs of the target audience. With regard to the work's translations into Turkish, there has been, at a large extent, an assimilative approach, conveying the spirit of the target culture. This tendency has been manifested, among others, in nationalistic and religious references which are not necessarily foreseen by the original text. Concerning ethos and morality, the central didactic axis and humanistic values of the book have been preserved, even though emphasis has not been always given on the same moral aspects highlighted in the original work. In certain Turkish translations, there has been an indisputable tendency to bring the book and its heroes closer to the values of Islam. At this point, we should be reminded that Islam is more than a religion; it is an attitude towards life and people, a daily practice, a tradition and possibly an armor against the 'temptations' and 'immoralities' of the 'Western world' (Mdallel, 2003; Sallah \& Howson, 2007). The emphasis on the importance of the obedience to Islamic values and practices could be interpreted as a defense against globalization and a way to preserve the uniqueness of a nation's identity. Let us keep in mind, that, despite the fact that Turkey is considered to be a secular state, in the practical Turkish reality, religion is strongly connected with "turkishness". In this sense, Islamic values are promoted as "better" or "higher" compared to "other" ideals and in particular, the principles and traditions of the West, which are featured as the tempting sinner. 
According to Gillian Lathey (2006, p. 9): "reductive representations of other nationalities or ethnic groups in children's literature result either from assumptions that children cannot process the complexity of difference, or from an adult consensus as to the image of another nationality to be presented to the young in any given historical period". It is also a fact, that, when a nation feels weaker of threatened in a particular moment in time, then nationalism tends to grow stronger. In such cases, nationalist voices dominate social life and its reflections in art; this is a way to survive and have continuity by promoting one's ethnic values, especially among the younger generation. Children's literature is one of the most efficient means to promote values and ideas. In the Turkish translations examined within the framework of the study, a strong correlation between the surrounding sociopolitical reality and the ideology promoted by each translation has been observed. Different translation strategies have been employed in every decade to produce a result matching the profile and aspirations of each governmental system. The very same book has been translated into Turkish in different ways according to 'how secular' each ruling party has been. The more liberal the system is, the more tolerant translation is to the western values featured in the original text. When the values diachronically promoted by the respective government in Turkey become more conservative, the translated versions of the Adventures of Pinocchio published during these times are somehow Islamized or closer to the dominant ideals of the target-culture.

The translations into Greek do not deviate from the overall meaning, content and mood of the original work, although there are interventions in the text and occasional deviations from the narrator's tone. Furthermore, at certain points, one can feel the translators' struggle to come up with a cultural equivalent, ending up with a result which is either obscure or ambiguous. There have also been instances where translators have created a humorous effect, even though this was not present in the original text. These cases have not been cited in this paper.

Another significant remark is related with the state of recognition of a translator's work, in the sense of his or her "visibility" on the published book. From a total of 10 books studied, only two featured the name of the translator on the front cover. This is one of the many similar findings in the international bibliography showing that, despite the significance of his/her contribution, a translator's presence is still often in the shadow.

\section{References}

Alvstad, C. (2003). Publishing Strategies of Translated Children's Literature in Argentina: A Combined Approach. Érudit, Meta: Traduction pour les enfants, 48(1-2), 266-275. doi:10.7202/006973ar

Arslan, D. (2016). Translation, Obscenity and Censorship in Turkey: Avni insel as a Translator and Patron of Popular Erotic Literature (Doctoral dissertation or master's thesis Dokuz Eylül University, Izmir, Turkey). Retrieved from https://www.academia.edu/28302520/Translation_Obscenity and Censorship in I urkey Avni Insel as a Translator and Patron of Popular Erotic Literature

Cusatelli, G. (Ed.) (2002). Pinocchio Esportazione: Il burattino di Collodi nella critica straniera. Roma: Armando Editore.

Even-Zohar, I., \& Toury, G. (1981). Introduction: Translation Theory and Intercultural Relations. Special issue of Poetics Today, 2(4), v-xi. 
Gavriilidis, S. (2011). Revisiting "The Adventures of Pinocchio". Keimena, 12 (in Greek). Retrieved from http://keimena.ece.uth.gr/t12/12_gavrihlidou.pdf

Gavriilidis, S. (2004). Pinocchio in Grecia. Pescia: Armando Editore-Fondazione Nazionale 'Carlo Collodi'.

Guglielmi, M. (2003). La traduzione letteraria. In A. Gnisci (Ed.), Letteratura Comparata (pp. 155184). Milano: Mondadori.

Goldthwaite, J. (1996). The Natural History of Make-Believe: A Guide to the Principal Works of Britain, Europe, and America. New York \& Oxford: Oxford University Press.

Holmes, J. S. (2000). The Name and the Nature of Translation Studies. In L. Venuti (Ed.) \& M. Baker (Advisory Ed.), The Translation Studies Reader (pp. 172-185). London \& New York: Routledge.

Kansu-Yetkiner, N. (2014). Words Apart, Worlds Apart: Peritexts from Islamized Translations of World Classics in Children's Literature. Children's Literature in Education, 45(4), 340-353.

Lathey, G. (2010). The role of Translators in Children's Literature: Invisible Storytellers. New York and London: Routledge.

Lathey, G. (Ed.) (2006). The Translation of Children's Literature: A Reader. Clevedon: Multilingual Matters.

Marcheschi, D. (Ed.) (1995). Carlo Collodi. Opere. Coll. “I Meridiani”. Milano: Mondadori.

Mdallel, S. (2003). Translating Children's Literature in the Arab World. The State of the Art. Érudit Meta: Traduction pour les enfants, 48(1-2), 298-306. doi:10.7202/006976aradresse

Meek, M. (Ed.). (2001). Children's Literature and National Identity. London: Trentham Books.

Moschitta, M. (Ed.) (1990). Le Avventure di Pinocchio. Firenze: Editore Bulgarini.

Nikolajeva, M. (2006). What Do We Translate When We Translate Children's Literature? In S. Beckett \& M. Nikolajeva (Eds.), Beyond Babar: The European Tradition in Children's Literature (pp. 277-297). Lanham, Maryland-Toronto-Oxford: The Scarecrow Press.

O’ Sullivan, E. (2005). Comparative Children's Literature. New York: Routledge.

Oittinen, R. (2000). Translating for Children. New York \& London: Garland Publishing.

Paruolo, E. (2001). The World of Pinocchio. Adventures in Languages and Cultures. In L. Tosi (Ed.), Hearts of Lightness. The Magic of Children's Literature (pp. 69-99). Cafoscarina, Venezia.

Paruolo, E. (2005). Adaptations of Pinocchio in English at the Turn of the 21st Century. In M. Bondi \& N. Maxwell (Eds.), Cross-Cultural Encounters: Linguistic Perspectives (pp. 238 -252) Roma: Officina Edizioni.

Pinsent, P. (Ed.) (2006). No Child Is an Island: The Case for Children's Literature in Translation. Lichfield: Pied Piper Publishing.

Sallah, M. (2011). Working with Muslim young people in the UK: considerations of race, religion and globalization. (Doctoral dissertation). De Montfort University, Leicester, UK. Retrieved from https://www.dora.dmu.ac.uk/xmlui/bitstream/handle/2086/6085/Sallah\%20thesis\%20no pub.pdf?sequence=1\&isAllowed $=\mathrm{y}$

Sallah, M., \& Howson, C. (Eds.) (2007). Working with Black Young People. Oxford: Russell House Publishing. 
Shavit, Z. (1995). The Historical Model of the Development of Children's Literature. In M. Nikolajeva (Ed.), Aspects and Issues in the History of Children's Literature (pp. 27-38). WestportConnecticut- London: Greenwood Press.

Shavit, Z. (1986). Poetics of Children's Literature. Athens and London: University of Georgia Press.

Toury, G. (1995). Descriptive translation studies and beyond. Amsterdam \& Philadelphia: John Benjamins Publishing.

Venuti, L. (1995). The Translator's Invisibility. London: Routledge.

Venuti, L. (1986). The Translator's Invisibility. Criticism, 28(2), 7-28. 